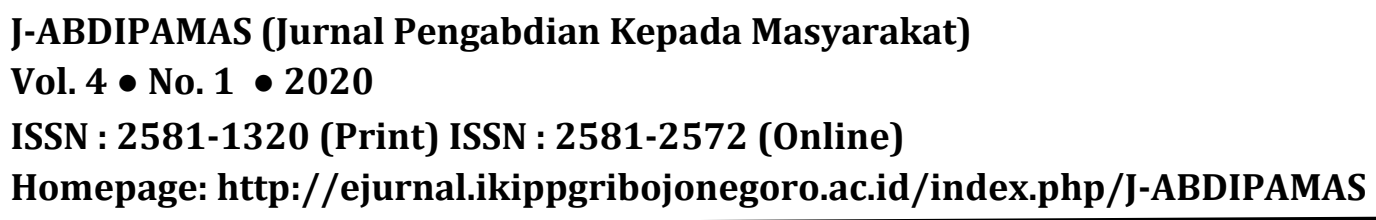

\title{
PEMANFAATAN LIMBAH RUMAH TANGGA (KANTONG PLASTIK DAN BOTOL)
}

\author{
Aisyah Tulfitri ${ }^{1}$, Emma Lilianti $^{2}$ \\ 1Universitas PGRI Palembang, email: aisyatulfitri05@gmail.com \\ 2Universitas PGRI Palembang, email: emmaliliantiok@gmail.com
}

\begin{abstract}
Plastic bottles have a high enough resistance, so they don't break easily. Therefore, if used as an object of use value will also produce products that are not easily destroyed. For this reason, the Utilization of Plastic Bottle Waste is used as something that has a selling value. This activity is carried out by the PKM-Entrepreneurship team, Accounting Economics Program. The basis of this activity is the concern for environmental sustainability and human creativity in creating. The outputs of the PKM-Entrepreneurship activities are 3 types of product creations and innovations for household needs, namely sandals, decorative lamps and wall hangings. The results of this activity are published through posters and scientific journals. There are many benefits taken from this activity, such as reducing environmental pollution, managing household waste into high-value creative products, increasing creativity and innovation in business opportunities and creating jobs for the community, and improving hygiene because waste treatment works better.
\end{abstract}

Keywords: waste, plastic bottles, household products

\begin{abstract}
ABSTRAK
Botol plastik memiliki ketahanan yang cukup tinggi, sehingga tidak mudah hancur. Oleh karena jika dimanfaatkan sebagai benda bernilai guna juga akan menghasilkan produk yang tidak mudah hancur. Untuk itu dilakukan Pemanfaatan Limbah Botol Plastik Untuk dijadikan sesuatu yang mempunyai nilai jual. Kegiatan ini dilakukan oleh tim PKM-Kewirausahaan, Program Ekonomi akuntansi. Dasar dari dilakukannya kegiatan ini adalah kepedulian terhadap kelestarian lingkungan dan kreativitas manusia dalam berkreasi. Luaran dari kegiatan PKM-Kewirausahaan adalah 3 jenis produk kreasi dan inovasi untuk kebutuhan rumah tangga yaitu sandal kreasi, lampu Hias, dan hiasan dinding. Hasil dari kegiatan ini di publikasikan melalui poster, dan jurnal ilmiah. Ada banyak manfaat yang diambil dari kegiatan ini, seperti mengurangi pencemaran lingkungan, mengelola limbah rumah tangga menjadi produk kreatifyang bernilai tinggi, meningkatkan kreativitas dan inovasi peluang usaha dan menciptakan lapangan pekerjaan untuk masyarakat, serta meningkatkan kebersihan karena pengolahan limbah berjalan lebih baik.
\end{abstract}

Kata Kunci: limbah, botol plastik, produk rumah tangga

\section{PENDAHULUAN}

Komposisi sampah atau limbah plastik yang dibuang oleh setiap rumah tangga adalah 9,3\% dari total sampah rumah tangga. DiJabotabek rata-rata setiap pabrik menghasilkan satu ton limbah plastik setiap minggunya. Jumlah tersebut akan terus bertambah, disebabkan sifat-sifat yang dimiliki plastik, antara lain tidak dapat membusuk, tidak terurai secara alami, tidak dapat menyerap air, maupun tidak dapat berkarat, dan pada akhirnya akhirnya menjadi masalah bagi lingkungan. Sampah adalah sesuatu yang tidak digunakan,tidak dipakai, tidak disenangi atau sesuatu yang dibuang berasal dari kegiatan manusia dan tidak terjadi dengan sendirinya (Wahyono (2012).

Plastik juga merupakan bahan organik buatan yang tersusun dari bahan-bahan kimia yang cukup berbahaya bagi lingkungan. Limbah dari plastik ini sangatlah sulit 
untuk diuraikan secara alami. Untuk menguraikan sampah plastik itu sendiri membutuhkan kurang lebih 80 tahun agar dapat terdegradasi secara sempurna. Langkah positif untuk pengurangan sampah melalui kampanye 3R yaitu reduce (mengurangi), reuse (menggunakan kembali) dan recycle (mendaur ulang). sehingga dapat menjadi adanya nilai jual dan bermanfaat bagi masyarakat untuk menghiasi rumah dengan hasil kreasi dari limbah rumah tangga. Melalui pengamatan kondisi lingkungan tersebut muncul ide kreatif untuk memanfaatkan limbah plastik dan botol untuk menjadi hiasan rumah dan dapat membantu megurangi sampah, dengan adanya Program Kreativitas Mahasiswa Kewirausahaan (PKM-K) kami semakin semangat dalam melakukan usaha ini dengan ikut berperan serta dalam program tersebut.

Manfaat daur ulang dari Program Kreativitas Mahasiswa Kewirausahaan (PKMK) yang ada disekitar kita dapat mengurangi pencemaran lingkungan, mengelola limbah rumah tangga menjadi produk kreatif yang bernilai tinggi, Meningkatkan kreativitas dan inovatif dalam terciptanya peluang usaha baru bagi mahasiswa yang bermanfaat dan tepat guna bagi masyarakat, dan menciptakan lapangan pekerjaan untuk masyarakat, serta tingkat kebersihan pun akan meningkat jika pengelolaan limbah berjalan dengan baik. Kompetitor dalam pemasaran produk "Sandal kreasi, lampu hias dan hiasan dinding" ini masih belum banyak ditemui di daerah palembang, jadi dalam pelaksanaan penjualan relatif mudah. Dalam menjaga persaingan dengan kompetitor yang ada dalam pelaksanaan penjualan, kami menjual dengan harga relatif murah.kami juga selalu menjaga kualitas mulai dari aspek ketahanan, kekreativitasan hingga strategi penjualan

\section{METODE PELAKSANAAN}

Produksi maupun dalam proses pemasaran. Secara umum, tahapan pelaksanaan kegiatan ini dapat disajikan melalui diagram berikut Diagram 1. Selama pelaksanaan kegiatan, metode yang diterapkan dalam proses produksi adalah metode direct selling. Metode ini diterapkan dengan tujuan agar pelaksanaan proses produksi dapat terlaksana secara efektif.

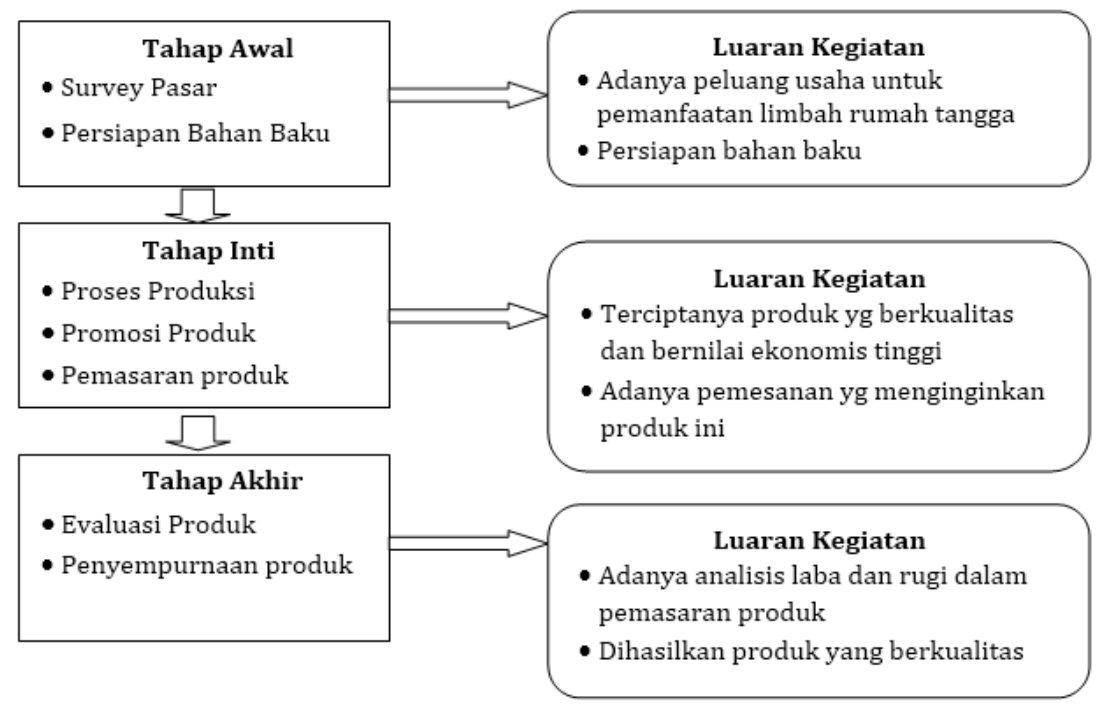

Diagram 1. Metode Pelaksanaan 


\section{Survey Pasar}

Survey pasar dilakukan dengan cara melihat peluang yang ada, serta pengecekan wilayah dan wawancara dengan berbagai kalangan masyarakat karena Produk yang dibuat yaitu sandal kreasi dari kantong plastik, lampu hias kamar serta hiasan dinding dari botol bekas. Kami membuat sandal dengan sampah kantong plastik bekas. Masyarakat belum pernah melihat kerajinan tangan berbahan baku plastik dalam bentuk sandal yang cantik, Karena sebagian besar masyarakat hanya membuat kerajinan kantong plastik menjadi bunga atau tas .maka hal ini akan menjadi hal baru bagi mereka dan pastinya menarik perhatian dan minat masyarakat.

Kemudian memperhitungkan saingan dari produk yang menyerupai produk (Sandal kreasi, Lampu hias, dan hiasan dinding). Produk lampu hias merupakan produk yang sebagian sudah ada juga yang menjual, tetapi sangat jarang ditemui. Dalam hal ini produk yang akan kami buat memiliki daya tarik yang berbeda dilingkungan sekitaran kota palembang khususnya bagi masyarakat sekitar.

Direct selling juga diterapkan secara langsung oleh tim pelaksana dalam memasarkan produk ini. Jadi metode ini diterapkan melalui sarana facebook, WhatsApp, dan Instagram, serta bazar dan biasanya di rumah atau tempat sekolah, atau pengeceran dan tempat-tempat lain melalui penjelasan atau peragan produk-produk oleh penjual. Selama proses/produksi, kualitas serta efektivitas kegiatan selalu dievaluasi dengan mengacu pada hasil kegiatan yang telah dilaksanakan sebelumnya. Hasil tersebut juga dievaluasi melalui bimbingan dosen pembimbing PKM.

Usaha ini dilaksanakan dengan memberdayakan ketua dan anggota tim mahasiswa yang berperan sebagai direksi. Dalam usaha ini semua anggota memiliki tugas masingmasing, yakni ketua, produksi, dan marketing. Untuk tim produksi memiliki tanggungjawab untuk menangani proses produksi dari pembuatan hingga pengemasan. Tim usaha yang disebut marketing ini memiliki tugas dan tanggungjawab melakukan promosi serta melakukan pemasaran. Tempat penjualan dari hasil karya limbah rumah tangga ini terletak Di Jakabaring Sport City,bazaar kambang iwak ,di bazar universitas PGRI pelembang, wilayah sekitar Palembang dan via online.

\section{Persiapan}

a. Lokasi Produksi PKM-K

Pada produksi limbah rumah tangga ini dilakukan dirumah salah satu anggota kelompok.

b. Alat dan Bahan:

Ada pun alat dan bahan yang digunakan dalam pembuatan limbah rumah tangga yaitu : Gunting, Cutter, Penggaris, Tembakan Lem, Lem tembak, Lem kayu, Kardus, Kantong plastik, Pulpen, Karet Gelang, Botol bekas, Sendok Plastik, Kertas Hvs Warna, Pylox Warna Kuning, Benang Wol, Jarum, Lampu, Kabel dan Manik-manik

\section{Proses Pembuatan Limbah Rumah Tangga}

Cara pembuatan Limbah Rumah Tangga dari bahan pokok seperti: Botol dan Kantong Plastik.

a. Langkah Pembuatan atau Proses dari limbah kantong plastik dan membentuknya menjadi karya seni indah dan bernilai tinggi, yaitu sandal kreasi : 
b. Langkah Pembuatan atau Proses dari limbah Botol dan membentuknya menjadi karya seni indah dan bernilai tinggi, yaitu Lampu Hias Kamar:

c. Langkah Pembuatan atau Proses dari limbah Botol dan membentuknya menjadi karya seni indah dan bernilai tinggi, yaitu Hiasan dinding:

\section{HASIL DAN PEMBAHASAN \\ Aspek Produksi}

Dalam hal ini kami mencari beberapa karyawan agar mempercepat proses produksi, maka dari itu secara tidak langsung kami sudah membuka peluang kerja baru bagi masyarakat sekitarnya.

1. Sandal kreasi, aspek produksinya yaitu :

a. Pengolahan produk

Kantong plastik yang masih layak pakai, yang biasanya hanya dibuang dicuci dan dikeringkan dipotong memanjang kemudian baru dikepang dan bentuk kardus sesuai dengan pola alas sandal kreasi dengan ukuran 38,39 dan 40 sebanyak 3 tingkat alas.
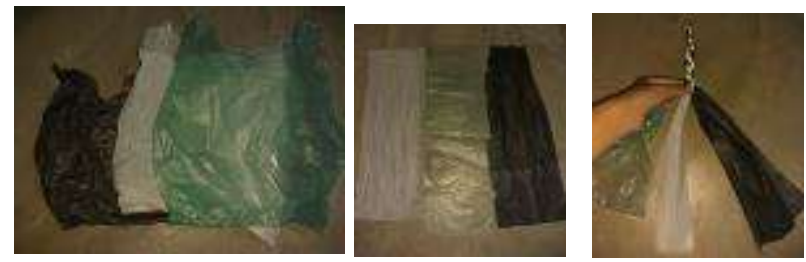

Gambar 1. Proses pembuatan kepangan dari plastik 3 warna
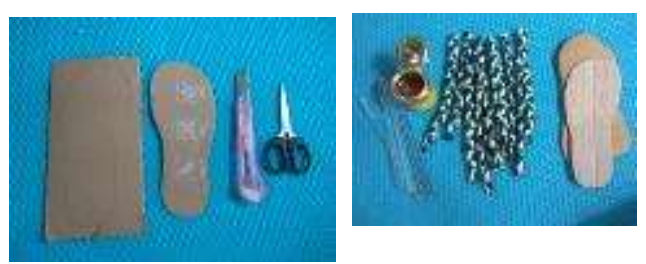

Gambar 2. Pembentukan alas sandal

b. Pembuatan

Kantong plastik yang sudah di bentuk kemudian di rekatkan diatas alas kardus yang pertama dan eratkan dengan alas kedua dan beri tali sandal diatasnya dengan kepangan plastik. Lalu eratkan dengan alas terakhir. Dan tutup bagian samping sandal dengan kepangan. Sandal siap digunakan

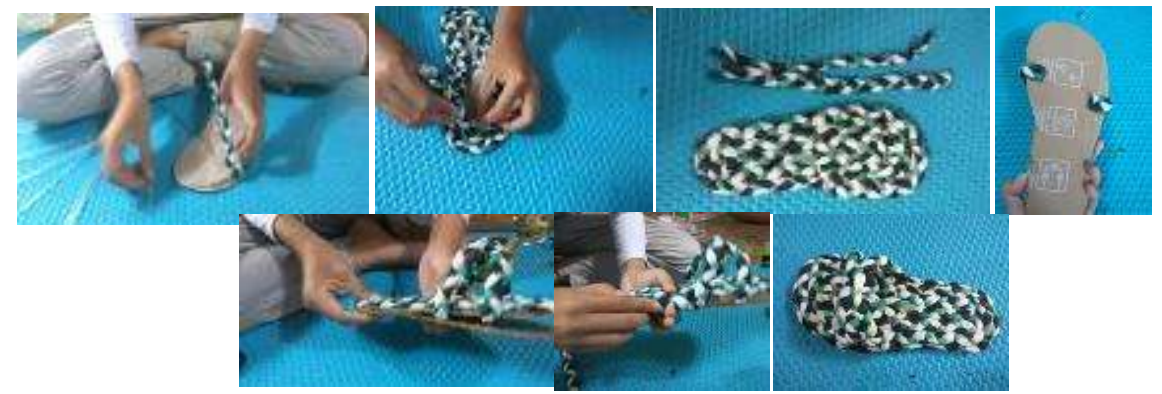

Gambar 3. Proses pembuatan sandal 
2. Lampu hias kamar, Aspek produksi meliputi :

a. Pengolahan produk

Pilih Botol bekas berukuran sedang yang masih layak pakai dicuci dan keringkan kemudian dipotong, siapkan sendok plastik dan potong bagian kepala.

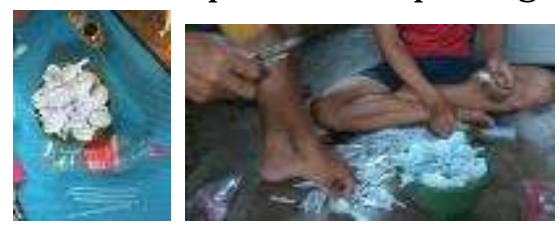

Gambar 4. Proses produksi sandal

b. Pembuatan

Susun sendok dengan cara menempel ke botol secara beraturan layaknya pola dari nanas ,lalu beri warna pada kepala sendok dengan pylox kuning.
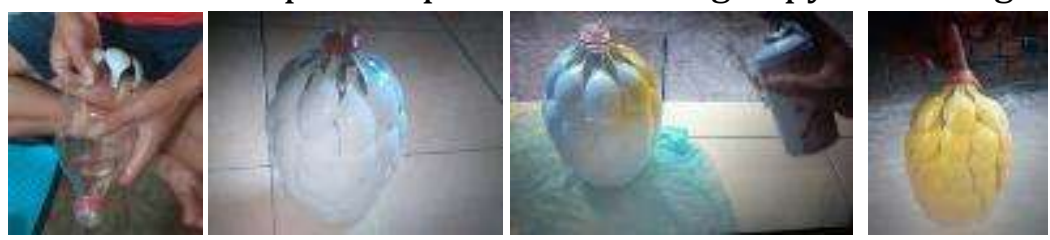

Gambar 5. Proses pembuatan sandal

c. Penyelesaian

Gunakan kertas kambing untuk membuat bentuk daun nanas lalu tempel dan beri lampu pada bagian dalamnya. Lampu siap digunakan dan dipasarkan.

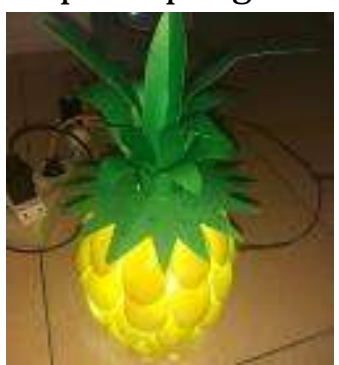

Gambar 6. Lampu hiasan nanas

3. Hiasan Dinding, Aspek produksi meliputi :

a. Pengolahan produk

Pilih Botol bekas berukuran kecil yang masih layak pakai dicuci dan keringkan lalu ambil bagian tengah tekan sampai gepeng dan potong kecil memanjang, setelah itu tekan salah satu ujung ketengah sehingga membentuk love (buat sebanyak 9 love untuk 1 hiasan).
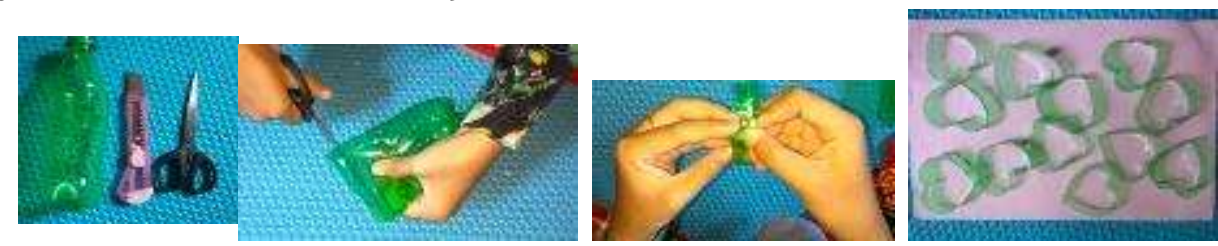

Gambar 7. Proses produksi

b. Pembuatan

Lilitkan benang wol kebentuk love sampai tertutup rapat. Bentuk kertas hvs warna menjadi lingkaran besar, kemudian buat pola bunga dan potong mengikuti 
pola bunga, gulung lalu lem, berikan manic ditengah bunga. Susun love yang sudah dililitkan dalam bentuk jajar genjang dan lem.
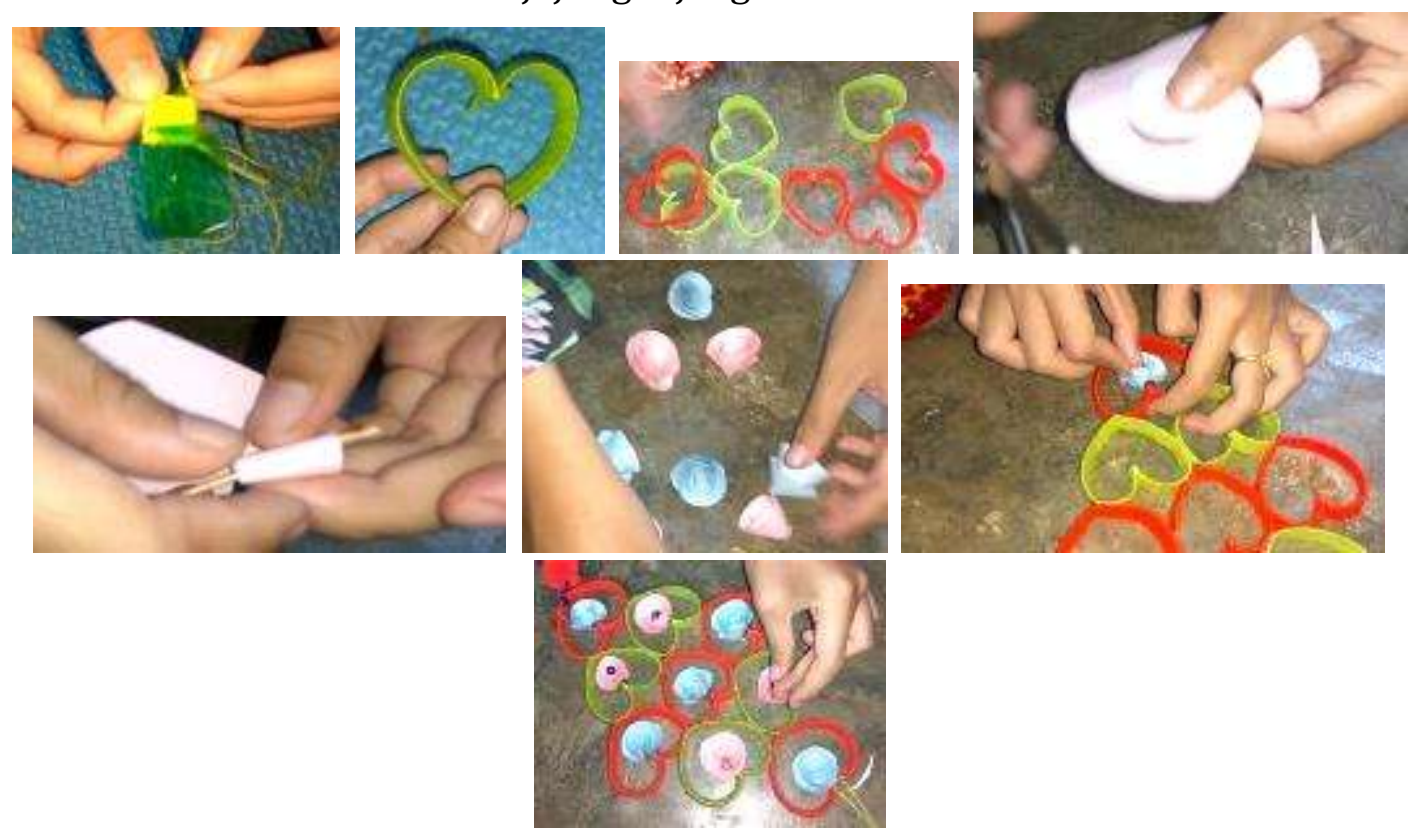

Gambar 8. Proses pembuatan hiasan

c. Penyelesaian

Kaitkan bandul wol hiasan ke love paling bawah dengan jarum, tali pada bagian paling atas love untuk menggantung hiasan. Hiasan dinding sudah siap di pakai.

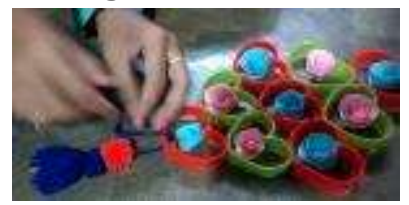

Gambar 9. Proses Penyelesaian

\section{Hasil yang Dicapai}

Dalam proses produksi semua berjalan dengan tepat waktu yaitu pembuatan produk terselesaikan 100\% (April-Juli 2019) dalam kondisi baik dari keuangan maupun hasil yang dicapai. Barang sudah mulai terjual dari awal proses pembuatan hingga saat ini, evaluasi dan penyempurnaan produk dan pemasaran masih terus kita lakukan setelah laporan kemajuan.

1. Ketercapaian Target Luaran

Target Luaran yang telah di capai diantaranya adalah:

a. Telah memproduksi produk sebanyak (20 bh sandal, 25 lampu hias, dan 50 hiasan dinding). Berikut salah satu contoh hasil:

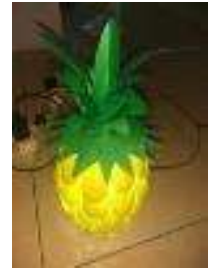

Lampu hias

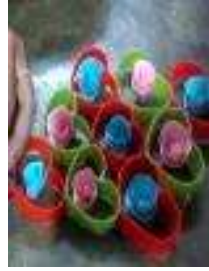

hiasan dinding

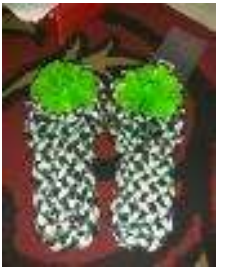

sandal kreasi 
b. Bagi masyarakat sekitar yang membantu akan diberi 1 produk gratis, sehingga secara tidak langsung melatih/menanamkan jiwa berwirausahaa kepada masyarakat dan juga melatih untuk kreatif agar bisa menerapkannya sendiri untuk berusaha.

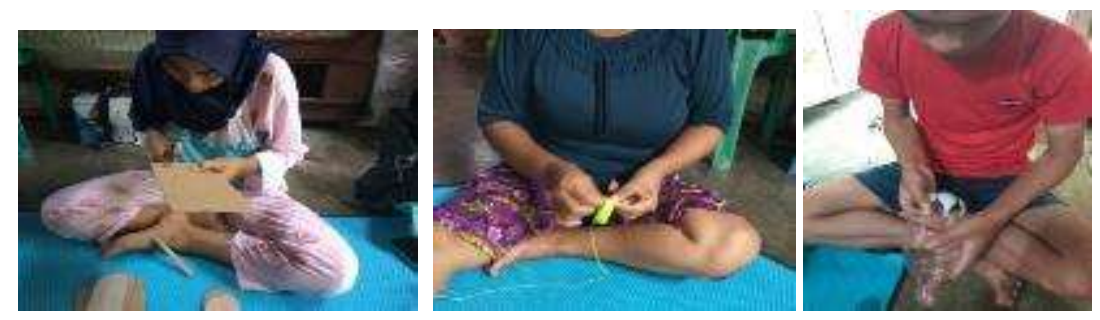

Gambar 10. proses kegiatan karyawan

c. Meningkatkan kreativitas dan inovatif dalam terciptanya peluang usaha baru bagi mahasiswa yang bermanfaat dan tepat guna bagi masyarakat.

d. kita dapat mengurangi pencemaran lingkungan, mengelola limbah rumah tangga menjadi produk kreatif yang bernilai tinggi.

2. Permasalan dan Penyelesaian

Masalah yang sering dihadapi adalah:

a. Kondisi dimana saat aktifitas perkuliahan berada pada saat libur panjang yang harus memisahkan seluruh anggota, kami atasi dengan proses pembuatan produk dilakukan secara individual di rumah masing-masing serta menambah beberapa karyawan untuk membantu mempercepat proses produksi serta secara tidak langsung melatih masyarakat untuk bisa berwirausaha sendiri.

b. Konsultasi antara tim menjadi terganggu karena terhambatnya jaringan internet diwilayah masing-masing, dapat kami atasi dengan mengganti operator dan kecepatan inteernet tinggi.

\section{Potensi Hasil}

Potensi hasil produksi Sandal kreasi, lampu Hias dan hiasan dinding, yaitu:

1. Meningkatnya nilai guna kantong plastik dan botol bekas yang biasanya menjadi sampah yang sulit untuk diuraikan.

2. Menambah penghasilan mahasiswa khususnya bagi yang tidak mampu dan juga masyarakat sekitar di palembang

3. Menambah penghasilan mahasiswa dengan menciptakan peluang usaha baru dengan memanfaatkan limbah rumah tangga.

Potensi bisnis kerajian masih memungkinkan untuk dikembangkan, dikarenakan Program ini merupakan program pertama yang dikembangkan dikawasan palembang, sehingga pesaing hampir bisa dikatakan minim. Tetapi apabila pesaing dengan produk dari bahan baku lain, produk ini masih memiliki kelebihan tersendiri seperti harga yang sangat terjangkau serta kualitas yang bagus. Kerajinan sandal kreasi, hiasan dinding serta lampu hias jarang ditemui di kawasan Palembang dengan bahan baku kantong plastik yang biasanya hanya digunanakan menjadi bunga atau tas dan botol yang hanya di daur menjadi vas bunga atau lainnya yang sudah umum dimasyarakat. Produk 
pemanfaatan limbah rumah tangga 3 produk ini mendapatkan peluang didalam pasar penjualan kerajianan, dikarnakan bentuk yang unik dan terbilang langka di daerah Palembang.

\section{Manajemen Usaha}

Biaya produksi akan menetukan harga jual sekaligus dapat diproyeksi keuntungan dari suatu usaha. Berikut ini perhitungan untuk pembuatan produk "Sandal Kreasi, Lampu Hias, dan Hiasan dinding" untuk satu kali proses produksi adalah sebagai berikut:

1. Sandal Kreasi

\begin{tabular}{lc}
\hline Modal produksi 20 buah Sandal & Rp 375.000 \\
\hline Bahan baku & Rp 375.000 \\
\hline Harga jual produk 20 pasang dengan harga @30.000 & Rp. 600.000 \\
\hline Revenue / cost ratio $=\frac{600.000}{375.000}=1.6$ & \\
\hline
\end{tabular}

Perhitungan diatas adalah perhitungan untuk satu kali proses produksi yang membutuhkan waktu sekitar 1 hari/orang. atau alokasi waktu (10 jam/minggu menghasilkan 1 produk).

2. Lampu Hias

\begin{tabular}{lr}
\hline Modal produksi 25 buah Lampu hias & Rp 800.000 \\
\hline a. Bahan baku & Rp 700.000 \\
b. Biaya pewarnaan & Rp. 100.000 \\
\hline Harga jual produk 25 pasang dengan harga @50.000 & Rp. 1.250 .000 \\
\hline Revenue / cost ratio $=\frac{1.250 .000}{800.000}=1.7$ & \\
\hline
\end{tabular}

Perhitungan diatas adalah perhitungan untuk satu kali proses produksi yang membutuhkan waktu sekitar 5 jam/orang. atau alokasi waktu (10 jam/minggu menghasilkan 4 produk).

3. Hiasan Dinding

\begin{tabular}{lc}
\hline Modal produksi 50 buah hiasan dinding & Rp 525.000 \\
\hline Bahan baku & Rp 525.000 \\
\hline Harga jual produk 50 pasang dengan harga @15.000 & Rp. 750.000 \\
\hline Revenue / cost ratio $=\frac{750.000}{525.000}=1.4$ & \\
\hline
\end{tabular}

Perhitungan diatas adalah perhitungan untuk satu kali proses produksi yang membutuhkan waktu sekitar 4 jam/orang atau alokasi waktu (20 jam/minggu menghasilkan 5 produk).

\section{Pemasaran}

Berdasarkan hasil PKM target pemasaran barang ini sasaran utamanya meliputi segmen umum, pelajar, masyarakat sekitar dan lingkungan pendidikan di kota palembang, juga pemenuhan pesanan yang datang langsung kepada kami untuk produkproduk dari usaha kreativitas kami tersebut. Juga dari lingkungan kampus/kost-kostan dan rumah tangga, Selain itu link pemasaran juga dilakukan melalui media sosial dan promosi antara lain:.

1. Memasarkan melalui online:

- WhatsApp (0857-8871-0804 ; 0821-7660-9553 ; 0823-9525-9940)

- Facebook (Aisya Tulfitri) 
- Instagram (aisyatfpkm_k)

- Line (aisyatf)

2. Mengikuti Bazar/Pameran

- Bazar yang diadakan Universitas PGRI Palembang

- Bazaar Jakabaring Sport City

- Bazar Kambang Iwak

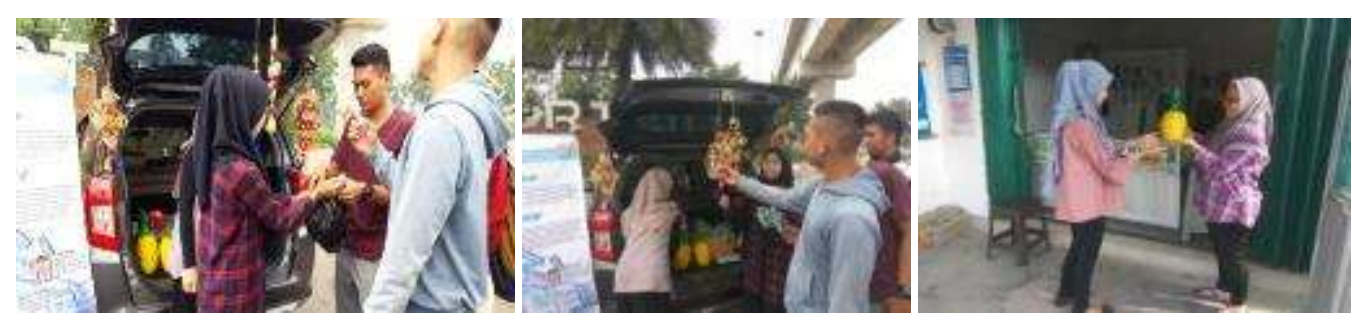

\section{SIMPULAN}

Berdasarkan kegiatan PKM yang telah dilaksanakan dapat disimpulkan bahwa Program Kreativitas Mahasiswa (PKM-K) pemanfaatan limbah rumah tangga (kantong plastik dan botol) telah mencapai target capaian pembuatan produk dan pemasaran sehinggan menghasilkan Break Event Point (BEP). Produk pemanfaatan limbah rumah tangga 3 produk ini mendapatkan peluang didalam pasar penjualan kerajianan, dikarnakan bentuk yang unik dan terbilang langka di daerah Palembang

\section{DAFTAR RUJUKAN}

Wahyono, E.H. dan Sudarno. N. 2012.Pengelolaan Sampah Plastik:Aneka kerajinan dari Sampah Plastik. Yapeka, Bogor

http://griyagawe.com/2010/02/fajar-purwaningsih-perajin-sampah-daur-ulang/ Yapeka, Agustus 2011.Laporan program pengelolaansampah rumah tangga.Coca-cola foundation Indonesia-yapeka https://www.hipwee.com/tips/25-kreasi-kantong-plastik-yang-nggak-malu-maluinkalau-dipakai-kemana-mana-hasilnya-bagus-semua/

https://www.duniabelajaranak.id/craft/membuat-sandal-dari-kardus-bekas/ 
162 J-Abdipamas, Vol. 4, No. 1 April, 2020 